\title{
術中出血に対する血液製剂使用の現状
}

\author{
川崎医科大学麻酔・集中治療医学 \\ 福井明
}

\section{A Study of the Intraoperative Blood Transfusion in Patients with Blood Loss.}

\author{
Akira FUKUI
}

Department of Anesthesiology and Intensive Care Medicine, Kawasaki Medical School

当院での $2,000 \mathrm{ml}$ 以上の術中出血症例に対する血液製剤使用の現状を過去 10 年間にわたり検討した。

自己血輸血がある群では, ない群に比して同種血輸血使用量減少, 術中出血量減少, ヒト赤血球濃厚液 (CRC) 投与を開始する時点での術中出血量の增加と同種血液輸血開始時のへマトクリット值低下, CRCのcrossmatchtransfusion ratio（C/T ratio）低下を認めた。そして，自己血輸血が存在することは，術者並びに麻酔科医の輸 血に対する意識の変化をもたらし, 同種血輸血を可能な限り回避し, 血液製剂の有効利用を行う努力をもたらし た。

しかし, 予定・緊急手術別で $\mathrm{C} / \mathrm{T}$ ratioを検討した場合, 緊急手術症例で $\mathrm{C} / \mathrm{T}$ ratioが高くなり, 緊急手術時で の準備血液量予想が困難であった。

索引用語：術中出血 (Intraoperative blood loss), 自己血輸血 (autotransfusion), 血液製剂有効利用 (Appropriate blood transfusion), 交差試験単位数／輸血血液単位数比（crossmatch-transufusion ratio）

\section{はじめに}

同種血輸血の合併症が問題化され，同種血輸血 の適正使用, 自己血輸血の推進が行われている。 当院でのType and Screen (T\&S) の導入, 最大 手術血液準備量 (MSBOS) の作成に向けて, 術中 出血と輸血の現状を明かにする目的で今回の調査 を行った。

\section{対象および方法}

当院で術中出血に対する血液製剂使用基準作 成 ${ }^{1)}$ との実施が行われた後の1987年から1996年 末までの 10 年間を調査期間とした。この中で, 当 科管理下に全身または脊椎麻酔で手術が行われ， 術中出血量が $2,000 \mathrm{ml}$ 以上となった 16 歳以上の症 例を对象とした。しかし, 体外循環使用手術症例,
術前に出血傾向（抗凝固療法中, 肝硬変）のある 症例は除外した。

これら症例を麻酔記録より，出血量と自己血輸 血の有無により 4 群に分けた。すなわちA群は, 術 中出血量が $4,000 \mathrm{ml}$ 以内で自己血輸血無し, B群 は, 術中出血量が $4,000 \mathrm{ml}$ 以内で自己血輸血有り, C群は, 術中出血量が $4,000 \mathrm{ml}$ 以上で自己血輸血無 し, D群は, 術中出血量が $4,000 \mathrm{ml}$ 以上で自己血輸 血有りとした。そして, 患者背景因子の, 年齢(歳), 性別 (男/女), 身長 $(\mathrm{cm})$, 体重 $(\mathrm{kg})$, 予定・ 緊急手術別比, 手術時間 (min), 麻酔時間 (min), 尿量 $(\mathrm{ml})$ を調查した。また, 術中出血量と各血 液製剂・輸液製剂使用量を調査した。血液製剤は, 同種血輸血ではヒト赤血球濃厚液（CRCまたは $\mathrm{RC}-\mathrm{MAP})$, 新鮮凍結七ト血漿(FFP), 濃厚血小 板血漿 (PC) それぞれの準備量, 追加量, 使用量, 
crossmatch-transfusion ratio $(\mathrm{C} / \mathrm{T}$ ratio $)$ を検 討した。また自己血輸血では貯血式, 術中回収式, 希勫式それぞれの施行症例数・準備量または回収 量・使用量を検討した。さらに人加熱血漿蛋白 $(\mathrm{PPF})$, 膠質液, 晶質液それぞれの使用量, 各種 血液製剂使用開始時の術中へマトクリット值

(Ht) と出血量との推移についても検討した。 記録記載に不備があり,これらの調查項目の判 定が不能であった症例は対象から除外した。

得られた值は, 平均值士標準偏差で表した。患 者背景因子の群間比較には一元配置分散分析法と $\chi^{2}$ 検定を，その他の群間比較には一元配置分散分 析法を用い， $\mathrm{p}<0.05$ 有意とした。

\section{成 績}

\section{1. 対象症例}

調査期間 10 年間の麻酔症例は 29,547 例で,この 内 2,483 例 $(8.4 \%)$ に血液製剤の投与が行われてい た。さらに 574 例(1.9\%)が術中出血量が2,000 ml以 上であった。574例中の357例が以下の理由で対象 から除外された。284例は体外循環使用手術症例, 38例は出血傾向の存在症例, 24例は 16 歳以下の症
例，11例は麻酔記録の不備による調査不能症例で あった。この結果, A群84例, B群58例, C群40例, D群35例が対象となった。

\section{2. 患者背景因子の検討 (Tab. 1 )}

Tab. 1に 4 群の背景因子を示す。背景因子の年 秢, 性別, 身長, 体重, 予定・緊急手術別比, 手 術時間，麻酔時間，術中尿量は，いずれの群間も 有意差を認めなかった。

\section{3. 術中出血量と各血液製犁使用量（Tab. 2 ）}

術中出血量は, A群 $3,124 \pm 645 \mathrm{ml}$, B群 $2,754 \pm$

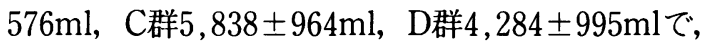
A-B，C-D群間の比較では自己血輸血を行った群 で出血量が少量であった $(\mathrm{p}<0.05)$ 。

CRC準備量は，A，B，C，D群それぞれ1,454土 $424,929 \pm 452,2,664 \pm 662,1,564 \pm 439 \mathrm{ml}$ で, A -B， A-C， C-D， B-D群間に有意差を認めた $(\mathrm{p}<$

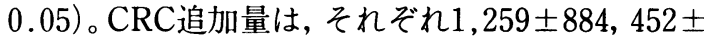

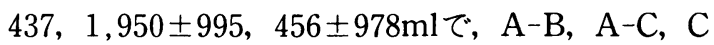
-D， B-D群間に有意差を認めた $(\mathrm{p}<0.05)$ 。 $\mathrm{CRC}$

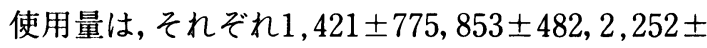
$1,127,1,088 \pm 895 \mathrm{ml}$ で, A-B, A-C, C-D, B-D 群間に有意差を認めた $(\mathrm{p}<0.05)$ 。 $\mathrm{CRC}$ の $\mathrm{C} / \mathrm{T}$

Tab. 1 Characteristics of patients

\begin{tabular}{|c|c|c|c|c|c|c|}
\hline Group & A & B & C & D & $p$ & value \\
\hline Blood $\operatorname{loss}(m \mid)$ & 2. $000 \sim 4.000$ & 2. $000 \sim 4.000$ & $>4.000$ & $>4.000$ & & - \\
\hline Autot ransfusion & - & + & - & + & & - \\
\hline Number of cases & 84 & 58 & 40 & 35 & & - \\
\hline Age(years) & $57.4 \pm 21.6$ & $59.8 \pm 19.7$ & $61.3 \pm 20.5$ & $62.3 \pm 30.5$ & & N. S. \\
\hline Sex(male/female) & $45 / 39$ & $25 / 33$ & $22 / 18$ & $16 / 19$ & & N. $S$. \\
\hline Heigh $(\mathrm{cm})$ & $161.3 \pm 10.4$ & $162.5 \pm 11.3$ & 159. $3 \pm 12.4$ & 163. $8 \pm 11.3$ & & N. S. \\
\hline Weight $(\mathrm{Kg})$ & $58.3 \pm 9.5$ & 59. $6 \pm 11.2$ & $60.6 \pm 10.3$ & $57.3 \pm 11.1$ & & N. S. \\
\hline Operat ion(elect ive/emergency) & $68 / 16$ & $43 / 15$ & $33 / 17$ & $26 / 9$ & & N. S. \\
\hline Duration of surgery(min) & $579 \pm 324$ & $587 \pm 287$ & $613 \pm 259$ & $608 \pm 238$ & & N. S. \\
\hline Duration of anesthesia(min) & $630 \pm 412$ & $624 \pm 309$ & $661 \pm 293$ & $665 \pm 262$ & & N. S. \\
\hline intraoperat ive urine dose $(\mathrm{ml})$ & $1838 \pm 951$ & $1664 \pm 994$ & $1935 \pm 1054$ & $1893 \pm 1091$ & & N. S. \\
\hline
\end{tabular}

values are mean $\pm S$. D.

NS: not significant 
日本外科系連合学会誌 第 23 巻 2 号

Tab. 2 Blood loss and treatments

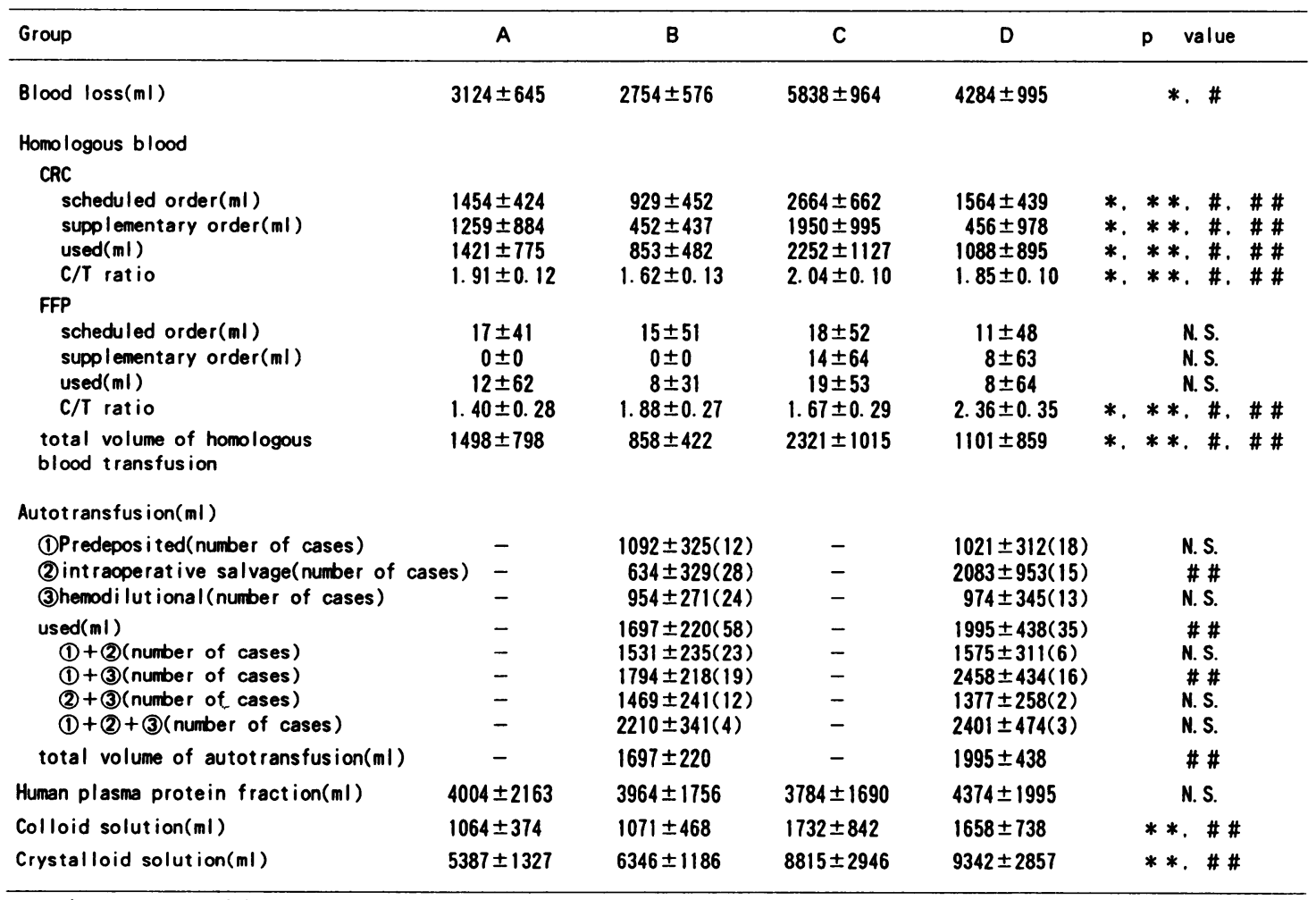

\footnotetext{
values are mean $\pm S$. D.

*: $p<0.05$ between group $A$ and group $B$ \$: : p<0. 05 between group $A$ and group $C$ $\#: p<0.05$ between group $C$ and group $D$ $\# \#: p<0.05$ between group $B$ and group $D$

NS: not significant
}

ratioは，それぞれ1.91 $\pm 0.12,1.62 \pm 0.13,2.04 \pm$ $0.10,1.85 \pm 0.10 て ゙, \mathrm{~A}-\mathrm{B}, \mathrm{A}-\mathrm{C}, \mathrm{C}-\mathrm{D}, \mathrm{B}-\mathrm{D}$ 群 間に有意差を認めた $(p<0.05)$ 。初回準備量のみ

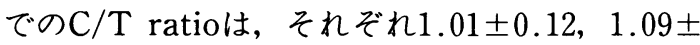
$0.13 ， 1.19 \pm 0.11 ， 1.44 \pm 0.13$ であった。予定手 術・緊急手術別のA，C群のC/T ratioは，それぞ

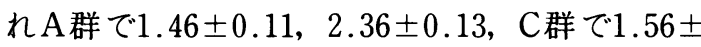
$0.12,2.52 \pm 0.13$ で, A, C群とも緊急手術で高値 を認めた（p<0.05）。

FFP準備量は，それぞれ $17 \pm 41 ， 15 \pm 51 ， 18 \pm$ 52, $11 \pm 48 \mathrm{ml}$, FFP追加量は, それぞれ $0 \pm 0$, $0 \pm 0 ， 14 \pm 64,8 \pm 63 \mathrm{ml}$, FFP使用量は, それ ぞれ $12 \pm 62,8 \pm 31,19 \pm 53,8 \pm 64 \mathrm{ml}$ で，いず れの群間にも有意差を認めなかった。FFPのC/T ratioは，それぞれ $1.40 \pm 0.28,1.88 \pm 0.27,1.67 \pm$ $0.29,2.36 \pm 0.35$ で, A-B, A-C, C-D, B-D群
間に有意差を認めた（ $\mathrm{p}<0.05 ） 。$

PCはいずれの群でも準備, 使用量は 0 であっ た。

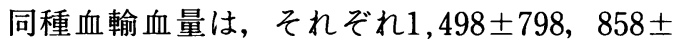
$422,2,321 \pm 1,015,1,101 \pm 859 \mathrm{ml}$ で, A-B, A$\mathrm{C}, \mathrm{C}-\mathrm{D}, \mathrm{B}-\mathrm{D}$ 群間に有意差を認めた $(\mathrm{p}<0.05)$ 。 自己血輸血量は，B，D群それぞれ貯血式で, $1,092 \pm 325$ (12)，1,021 \pm 312 (18) $\mathrm{ml}$ ，（施行症

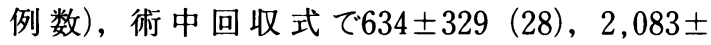
953(15) ml, 希釈式で954 $\pm 271(24), 974 \pm 345$ (13) $\mathrm{ml}$ で， D群の術中回収式で大量の自己血が得られ た（ $\mathrm{p}<0.05 ）$ 。自己血輸血法の組み合わせは，貯 血式と術中回収式併用がB，D群それぞれ $1,531 \pm$

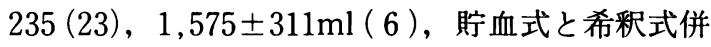
用が1,794 $\pm 218(19), 2,458 \pm 434(16) \mathrm{ml}$, 術中

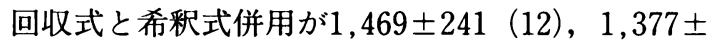


術中出血に対する血液製剂使用の現状

Tab. 3 Comparison of blood management practice

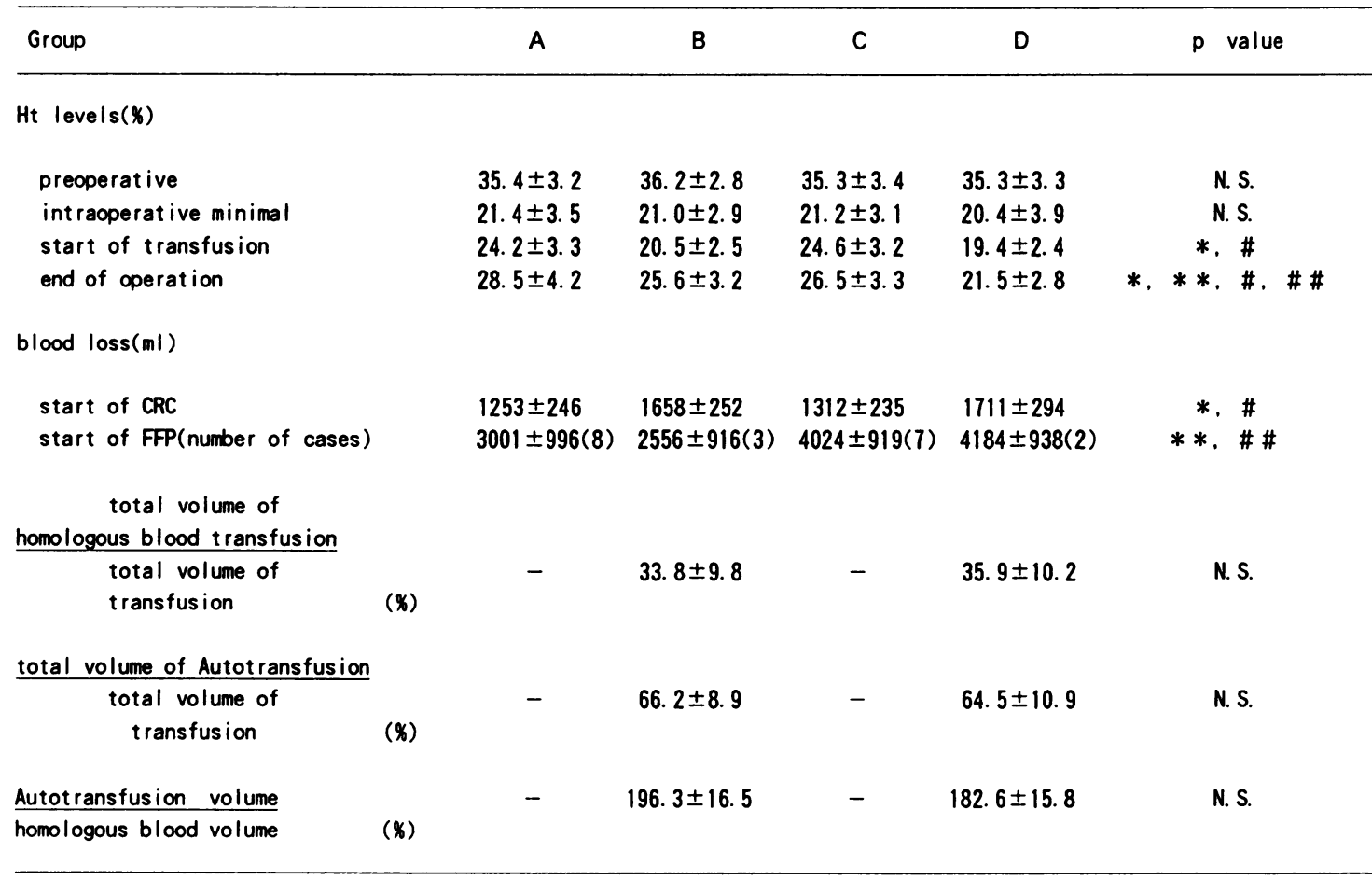

\footnotetext{
Values are mean \pm S. D.

*: $: p<0.05$ between group $A$ and group $B$

**: $p<0.05$ between group $A$ and group $C$

\#:p<0.05 between group $C$ and group $D$

$\# \#: p<0.05$ between group $B$ adn group $D$

NS: not significant
}

258 ( 2 ) $\mathrm{ml}$, 貯血式と術中回収式と希釈式併用が

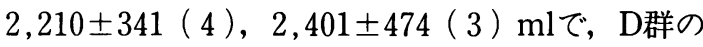
貯血式と術中回収式併用で大量の自己血が得られ た $(\mathrm{p}<0.05)$ 。また， B，D群それぞれ1,697士220， 1,995士438mlの自己血が術中にすべて返血され た。

PPFの使用量には, 各群間に有意差を認めなか った。

膠質液の使用量は，それぞれ $1,064 \pm 374$, $1,071 \pm 468,1,732 \pm 842,1,658 \pm 738 \mathrm{ml}$ で, A-C, B-D群間に有意差を認めた $(\mathrm{p}<0.05)$ 。 晶質液の使用量は，それぞれ $5,387 \pm 1,327$, $6,346 \pm 1,186,8,815 \pm 2,946,9,342 \pm 2,857 \mathrm{ml}$ で, $\mathrm{A}-\mathrm{C} ， \mathrm{~B}-\mathrm{D}$ 群間に有意差を認めた $(\mathrm{p}<0.05)$ 。

4. 各血液製剤使用時のHt值と使用割合 (Tab. 3 ) 術前と術中最低Ht值には各群間に有意差を認
めなかった。しかし，同種血輸血か自己血輸血返 血開始時の $\mathrm{Ht}$ 值は, A, B, C, D群それぞれ $24.2 \pm$ $3.3,20.5 \pm 2.5,24.6 \pm 3.2,19.4 \pm 2.4 \%$ で, A$\mathrm{B}, \mathrm{C}-\mathrm{D}$ 群間に有意差を認めた $(\mathrm{p}<0.05)$ 。さらに, 手術終了時の Ht值は, それぞれ $28.5 \pm 4.2,25.6 \pm$ $3.2,26.5 \pm 3.3,21.5 \pm 2.8 \%$ で, A-B, A-C, C -D，B-D群間に有意差を認めた $(\mathrm{p}<0.05)$ 。

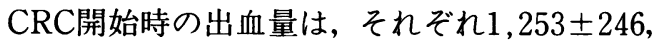
1,658 $252,1,312 \pm 235,1,711 \pm 294 \mathrm{ml}$ で, A-B, $\mathrm{C}-\mathrm{D}$ 群間に有意差を認めた $(\mathrm{p}<0.05)$ 。また, FFP 開始時の出血量は，それぞれ3,001士996（8),

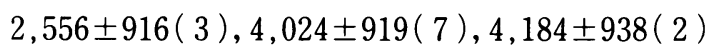
$\mathrm{ml}$ で, A-C, B-D群間に有意差を認めた $(\mathrm{p}<0.05)$ (施行症例数)。

全輸血に対する同種血輸血使用率は, B, D群そ れぞれ $33.8 \pm 9.8,35.9 \pm 10.2 \%$ ，全輸血に対する 
自己血輸血使用率は，それぞれ66.2 $28.9,64.5 \pm$ $10.9 \%$, 自己血輸血に对する同種血輸血使用率は,

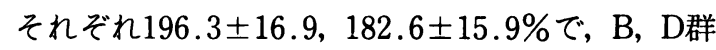
間に有意差を認めなかった。

\section{考察}

同種血輸血の副作用が認識され，自己血輸血の 普及, 血液代替物の研究が行われている。しかし, 臨床ではまだ同種血輸血に依存しなければならな いのが現状である。

このため, 厚生省薬務局より新鮮凍結血漿・ア ルブミン製剤・赤血球濃厚液の使用基準（1986年 8 月), 輸血療法の適正化に関するガイドライン (1989年 9 月)，血小板製剂の適正使用について （1994年 7 月）が発表された。そして, 術中の血 液製剤使用基準が示され, 同種血輸血の安易な利 用が戒められている。当科においても，1975年か ら希釈式自己血輸血の開始, 1982年から回収式自 己血輸血の開始，1987年から術中出血に対する血 液製剂使用基準作成と実施 ${ }^{1}$ ，1994年から貯血式 自己血輸血の開始と, 周術期患者の同種血輸血使 用の回避・減量に努力してきた。しかし残念なが ら，これらは各科ごとの努力であり，中にはこれ らの努力に異論を唱える科さえも存在した。また 当院では輸血部専任医師の不在, T\&Sの未導入, MSBOSの未作成と, 院内全体としてのバックア ップ体制が整備されていない。これらの反省より 1997年 2 月に, ようやく輸血療法適正使用小委員 会が発足し, 早急にT\&Sの導入とMSBOSの作成 を行うことが決議された。このため, 当院での術 中出血と輸血の現状を明かにする目的で今回の調 查を行った。

最近では自己血輸血法を用いることで，貯血， 希釈, 回収式法それぞれの組み合わせで出血量 2,000mlまでは, 無輸血で対処可能であると報告 されている2。循環血液量の $50 \%$ 以上の出血にな れば, 大量出血と定義され, $\mathrm{CRC}$ みで対処可能 の限界となる。したがって, 同種血輸血が必要と なる $2,000 \mathrm{ml}$ 以上の出血症例と, ほぼ成人の循環 血液量に相当する $4,000 \mathrm{ml}$ 以上の大量出血症例の 2 群に分類し, さらにこの 2 群を自己血輸血の施 行の有無で分類した 4 群間で, 血液製剂の使用状
況を検討した。

この結果, $4,000 \mathrm{ml}$ 以内の出血症例で $41 \%$, $4,000 \mathrm{ml}$ 以上の出血症例で $46 \%$ に自己血輸血が行 われ, 輸血量の $66 \%$ がB群で, $65 \%$ がD群で自己血 を用いて行われていた。また，自己血輸血がある 群 $(\mathrm{B}, \mathrm{D})$ では, ない群 $(\mathrm{A}, \mathrm{C})$ に比して, 同 種血輸血使用量の減少, 術中出血量の減少, $\mathrm{CRC}$ 投与開始時の術中出血量の増加と同種血輸血開始 時の Ht 值の低下 (可能な限り, 同種血輸血開始を 遅らせる)，CRCのC/T ratioの低下を認めた。同 種血輸血使用量が減少した点は, 自己血輸血があ る群では術中出血に対しては当然のごとくまず自 己血輸血から輸血を開始する。このため同種血輸 血の使用は, 予想以上に出血量が増加した場合, 準備した自己血輸血でも対処不可能な低Ht值に なった場合であった点が影響したと思われる。術 中出血量が減少した点は, 自己血を準備したと言 う事実が，外科医に無輸血手術をしようと言う認 識をもらたし，慎重な手術操作を行わせたのでは ないだろうか。CRC投与開始時の術中出血量の増 加と同種血輸血開始時の $\mathrm{Ht}$ 值の低下は, 可能な限 ク自己血輸血のみで手術を終了したい, 少しぐら いの低Ht值でも頑張ろうと言う考之を麻酔科医 にもたらし，同種血輸血開始を遅らせたのではな いかと思われる。そしてこれらの同種血輸血を回 避しようとする努力が, 同種血の準備量を減少さ せ, CRCのC/T ratio低下につながったと思われ る。新名主ら ${ }^{3}$ は, 自己血輸血導入後 3 年で, CRC 使用量が $30 \%$, FFP使用量が $50 \%$ 減少したと報告 し，これらを自己血輸血の派生効果と経済効果で あるとしている。また星(4), 自己血輸血の実施に より, 手術時の同種血輸血使用量が 4,000 単位から 2,500 単位へ減少し, 年間 1,000 万円以上の医療費 が節減されたと報告している。

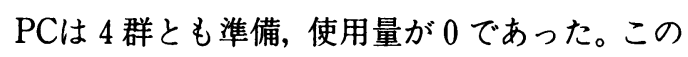
点は, PC入手に予約が必要なこと, 時間を要すこ と(午前中の注文で入手は夕方)， CRCと言えども 血小板が全血製剂と同量含まれている5)，などの 理由から術中はほとんど使用されなかったものと 思われる。このため, PCの使用は術後が主体とな っていた。

ガイドラインでは, 理想的な $\mathrm{C} / \mathrm{T}$ ratioは, 1.5 
以下としている6)。しかし, T\&Sの導入, MSBOS の作成を行っている光畑ら゙は3.8〜11.8, 加美長 ら ${ }^{8)} 1.9$ と報告にかなりの差がある。また予想外 の大量出血に遭遇することを考之れば, 2.5 以下が 妥当とする報告もなされている ${ }^{7,9)}$ 。今回の調査 で, CRCのC/T ratioは, A〜D群それぞれ1.91, 1.62, 2.04, 1.85であり, T\&Sの未導入, MSBOS の未作成状態の当院の現状としてはほぼ満足な值 であると思われる。

今回の対象は, $2,000 \mathrm{ml}$ 以上の術中出血であっ た。 $\mathrm{A} \sim \mathrm{D}$ 群それぞれの平均出血量は 3,124 , $2,754,5,838,4,284 \mathrm{ml}$ と大量であり, 初回準備し たそれぞれ1,454，929，2,664，1，564mlのCRCは， ほとんど術中に使用されていた。このため, 初回 準備量でのC/T ratioは，それぞれ1.01，1.09, $1.19,1.44$ とガイドラインの目標とする1.5以下に なった。しかし，A，B群のC/T ratioを予定手術・ 緊急手術別に検討した場合, 緊急手術でのC/T ratioはA，B群とも高値であった。したがって, 緊 急手術のような手術操作に必要な患者の情報が十 分得られず, 出血の予想がたてられない場合, 夜 間などで血液センターからの血液供給に時間が必 要な場合, 輸血に携わる（交差試験, 運搬) 人員 の確保が不可能な場合, など施設の置かれた条件 によってC/T ratioは, かなりの変化を受けるも のと思われる。すなわち，これらの場合ではどう しても血液供給の不安から, 余分に準備する傾向 にあること, 緊急手術は夜間帯が多く, 幾ら当院 のごとく好条件の施設 (各血液型ごとの院内予備 保存が, 約 $2,000 \sim 4,000 \mathrm{ml}$ あこと, 夜間であっ ても中央検查部技師による交差試験が可能で，追 加された血液もほぼ30分以内に患者投与の準備が 可能であること, 当院に在庫がなくても, 血液セ ンターから約 30 分で血液の供給が受けられるこ と)であっても多めの準備になり，C/T ratioを上 昇させたものと思われる。しかし, 萬代10)らの地方 中規模病院に置いても，1992年にC/T ratio1.36 を維持しており，各施設の置かれた条件を検討 · 理解し, 各施設の対策・改善・努力により $\mathrm{C} / \mathrm{T}$ ratio低下は可能と思われる。

\section{結語}

自己血輸血が準備されることで, 術中出血量の 減少, 同種血輸血使用量の減少, 血液製剤の有効 利用が行われた。 $\mathrm{C} / \mathrm{T}$ ratioはその施設の血液供 給体制に大きく影響された。緊急手術では，準備 血液量予想が困難なためC/T ratioが高くなっ た。

\section{参考文献}

1）福井 明, 木村健一, 遠藤恵美子他：術中出血に 対する血液製剂使用法. 日輸血会誌 $35 ： 332-$ 33, 1989

2) 冨士武史, 松井誠一郎, 三橋 浩他: 術中 - 術後 の回収式自己血輸血法の適応と限界. 整 - 災外 $38: 423-430,1995$

3）新名主宏一, 納 光弘: 自己血輸血の派生効果. 小児外科 $27: 1034-1039,1995$

4) 星 順隆：自己血輸血. 外科治療 $76: 36-44$, 1997

5）関口定美: 赤血球濃厚; 全成分血（Total Components Blood) としての適応.日輸血会誌 31 ： 407-410, 1985

6）血液事業検討委員会：血液製剂使用適正化小委 員会報告，日輸血会誌 $32: 491-498 ， 1986$

7）光畑裕正, 松元 茂, 大高公成他：手術部におけ る術中外科輸血の分析および最大血液準備量の 試み。日輸血会誌 $36: 587-592,1990$

8）加美長严由, 野村 努, 池田和真他 : 香川医科大 学附属病院におけるtype \& screenとmaximum surgical blood order scheduleの導入. 日輸血会 誌 $41: 435-439,1995$

9) Rouault C, Gruenhagen J : Reorganization of blood ordering practices. transfusion $18: 448$ 453, 1978

10）萬代良一, 桑原一志, 野坂修一他: 地方中規模病 院に置けるMSBOS, Type and Screen導入の試 み。日輸血会誌 $39: 944-951,1993$ 